\title{
Evaluasi Program Pembinaan Tenis Lapangan Pelti Kota Palembang
}

\author{
Herri Yusfi ${ }^{a}$, Hendra Mashuri ${ }^{b}$ \\ ${ }^{a}$ Pendidikan Jasmani dan Kesehatan FKIP Universitas Sriwijaya Palembang, Indonesia \\ ${ }^{b}$ Magister Keguruan Olahraga PPs Universitas Nusantara PGRI Kediri, Indoonesia
}

Corresponding author: hendramashuri@unpkediri.ac.id

A R T I CLE INFO

Article history:

Received 15 April 2019

Received in revised form 21

April 2019

Accepted 30 April 2019

Keywords:

Program Evaluation, Coaching,

Tennis

\begin{abstract}
A B S T R A C T
This study aims to evaluate Palembang PELTI tennis coaching program, evaluate PELTI management, athletes, coaches and assistant coaches, facilities and infrastructure, and government support for Palembang's tennis development program, evaluate the selection of coaches and athletes, fostering athletes, training programs, evaluating the PELTI work program and coordinating the tennis coaching program of the city of Palembang, and evaluating the success of the Palembang tennis development program. This study is a program evaluation study using the CIPP method using a qualitative approach. The population of this study was tennis athletes in Palembang. Data collection techniques are observation, in-depth interviews, documentation, and data triangulation. This study produces good context, sufficient input, sufficient process, and sufficient product. This study concludes that development program that is not clear from PELTI in improving athlete performance, input of PELTI development program is still lacking in the process of selecting athletes, coaches, assistant coaches and minimal funding from the government, process training program that is not going well, the health of athletes, coaches and assistant coaches who are not guaranteed by the government and there is no special transportation for athletes, and product Program PELTI Coaching has not been able to show results at the national level with real data and facts in the field.
\end{abstract}

\section{Pendahuluan}

Kemajuan prestasi olahraga merupakan tanggung jawab seluruh masyarakat yang mampu menyaring dan membina atlet dari level bawah. Hal ini harus terjadi mengingat prestasi olahraga tidak akan datang secara instan tetapi pencapaian prestasi olahraga secara optimal dapat diwujudkan melalui proses pembinaan secara terencana, berjenjang, dan berkelanjutan dengan dukungan ilmu pengetahuan dan teknologi keolahragaan. Hal ini telah diamanahkan dalam UU Nomor 3 Tahun 2005 pada pasal 20 ayat 3 bahwa olahrga prestasi dilaksanakan melalui proses pembinaan dan pengembangan secara terencana, berjenjang, dan berkelanjutan dengan dukungan ilmu pengetahuan dan teknologi keolahragaan.

Sumatera Selatan merupakan salah satu provinsi yang ditunjuk untuk menjadi tuan rumah
SEA GAMES ke 26 tahun 2011, ini menunjukkan bahwa daerah Sumatera Selatan sekarang ini merupakan daerah yang mulai berkembang di bidang olahraganya. Banyak sarana prasarana yang bertaraf internasional di bangun daerah ini sehingga sarana dan prasarana tersebut bisa dimanfaatkan untuk menunjang prestasi atlet daerah yang ada di SumSel. Dibalik semua ini dengan hanya sarana dan prasarana yang lengkap tidak cukup untuk menciptakan atlet-atlet yang berprestasi tetapi melalui program pembinaan prestasi yang sistematis dan terencana baru dapat menciptakan atlet yang berprestasi.

Cabang olahraga yang sampai sekarang belum bisa menunjukkan prestasi yang maksimal di tingkat nasional di Sumatera Selatan adalah cabang olahraga tenis lapangan. Hasil wawancara kepada pelatih tenis kota Palembang dan tim tenis PON Sumatera Selatan yaitu bapak Rizaldy Martin. S.Pd dan pelatih tim tenis POPWIL yaitu 
Dunika Rahayu. S.Pd. ditingkat provinsi tim kota Palembang selalu menjadi langganan juara umum untuk cabang tenis lapangan di pertandingan PORPROV.

\section{Tabel 1. Data Perolehan Medali PORPROV Sumatera Selatan Cabang Olahraga Tenis Lapangan}

\begin{tabular}{cll}
\hline NO & Tahun PORPROV & \multicolumn{1}{c}{ Perolehan Medali } \\
\hline 1 & PORPROV VIII (2002) & 2 perak, 1 perunggu \\
\hline 2 & PORPROV IX (2006) & 4 medali emas \\
\hline 3 & PORPROV X (2010) & 6 medali emas, 1 perak \\
\hline
\end{tabular}

Atlet tenis kota Palembang selalu mengirimkan atletnya untuk mewakili provinsi Sumatera selatan untuk bertanding di tingkat nasional, pada saat Pra PON atlet Sumatera Selatan semuanya berasal dari kota Palembang yaitu David Julianto, Trio Wardhana Yudistira, M. Syahrudin, Akbar Thio tapi . untuk cabang tenis lapangan tim tenis putra tidak lolos kualifikasi sedangkan tim tenis putri yang hampir semuanya merupakan atlet kota Palembang yaitu Suci Saraswati, Azika Olinda, Rara Tari dan Dian yang berasal dari Bangka Belitung lolos karena mendapatkan wild card untuk mengikuti perayaan PON ke 18 di Riau tahun 2012 , tetapi dalam pertandingan tim putri tidak pernah mengalami kemenangan dalam pertandingan. Pada kegiatan POPWIL tahun 2012 tim tenis Sumatera Selatan hampir semuanya di wakili oleh atlet kota Palembang juga tapi belum bisa menunjukkan prestasi yang diharapakan, terbukti pada pertandingan POPWIL zona 2 yang diikuti oleh 6 provinsi (DKI Jakarta, Jawa Barat, Lampung, Sumatera Selatan, Kalimantan Barat, Bengkulu) tim tenis putra hanya berada di peringkat ke 5 dan tim tenis putri hanya berada di pringkat ke 4 sedangkan untuk lolos ke tahap selanjutnya yaitu POPNAS harus masuk ke dalam peringkat 3 besar. Membuktikan bahwa di cabang ini, Sumatera Selatan belum dapat berbicara banyak dalam hal prestasi baik putra maupun putri. Sebagian besar atlet yang mewakili Sumatera Selatan berasal dari kota Palembang, hanya satu atlet yang berasal dari luar kota Palembang yaitu dari kabupaten Batu Raja. Membuktikan bahwa untuk sekarang kota Palembang lebih mendominasi cabang olahraga tenis di Sumatera Selatan dari pada kabupaten yang lain, akan tetapi atlet-atlet yang berasal dari kota Palembang belum bisa bersaing ditingkat Nasional.

Sumber daya manusia merupakan salah satu faktor minimnya prestasi atlet tenis lapangan kota Palembang di tingkat nasional, faktor lain yang menyebabkan minimnya prestasi atlet tenis kota Palembang yaitu kurangnya kompetisi-kompetisi yang di laksanakan di kota ini. Kompetisi di Palembang yang sering terlaksana pada saat even tahunan saja sepeti O2SN, POPDA, PORPROV. Minimnya kompetisi yang dilaksanakan sehingga menyebabkan atlet kurang jam terbang atau pengalaman bertanding, kompetisi juga merupakan salah satu aspek penting untuk pemanduan bakat (talent scouting) yaitu mencari atlet atau menjaring atlet yang berbakat dan dibina dengan baik. Cara pemanduan bakat yang umum adalah dengan menyelenggarakan pertandinganpertandingan sebanyak mungkin (Forum Olahraga dalam Wahjoedi, 2011:49)

Uraian diatas menunjukkan bahwa atlet tenis kota Palembang belum bisa memberikan prestasi yang untuk SumSel di tingkat nasional, sehingga menarik peneliti untuk melakukan sebuah penelitian terkait dengan program pembinaan prestasi yang diterapkan PELTI kota Palembang guna menunjang untuk meningkatkan prestasi atlet tenis lapangan di kota Palembang.

Program pembinaan tenis lapangan PELTI Kota Palembang perlu dilakukan evaluasi untuk untuk pengambilan keputusan atau penilaian. Jadi evaluasi program mempunyai tiga hal pokok yang penting, yaitu pengambilan data, penilaian, dan pengambilan keputusan.

Paton (2005) menjelaskan evaluasi program adalah proses pengambilan data yang sistematis untuk melakukan penilaian dan keputusan terhadap suatu program. Berdasarkan pendapat tersebut maka evaluasi program adalah sebuah proses, dimana proses harus sistematis dalam pengambilan datanya. Evaluasi digunakan untuk pengambilan keputusan atau peniaian. Jadi evaluasi program mempunyai tiga hal pokok yang pentting, yaitu pengambilan data, penilaian, dan pengambilan keputusan.

Hal penting dalam pengambilan data maksudnya bahwa evaluasi harus dilakukan secara sistematis dengan desain evaluasi (Dale dalam Ariyanto, 2015). Pengambilan data harus mempunyai perencanaan agar diperoleh data yang benar. Pengambilan data sistematis berarti bahwa pengambilan data harus disesuaikan dengan tahapan-tahapan dan prosedur yang telah ditetapkan dalam proses perencanaan evaluasi. Hali ini akan memberikan gambaran yang benar mengenai pelaksanaan program. Setelah pengambilan data, kemudian dilanjutkan dengan penilaian. 
Penilaian yang dilakukan berdasarkan faktafakta yang diperoleh dan pemberian kriteria terhadap objek-objek (Djaali dan Mujiono, 2008). Penilaian dapat dilakukan dengan cara membandingkan hasil pencapaian program dengan tujuan yang telah ditetapkan dalam perencanaan program. Hasil penilaian kemudian dijadikan sebagai dasar untuk menentukan keputusan-keputusan.

Model-model evaluasi program yang bisa dilakukan untuk mengevaluasi program pembinaan tenis lapangan PELTI Kota Palembang, diantaranya (1) Goal Oriented Evaluation Model, (2) Goal Free Evaluation Model, (3) Formatif Summatif Evaluation Model (4) Countennce Evaluation Model, (5) Responsive Evaluation Model, (6) CSE-UCLA Evaluation Model, (7) CIPP Evaluation Model, dan (8) Discrepancy Model. Namun, penelitian ini yang dipakai untuk mengevaluasi program dari berbagai model tersebut adalah model CIPP Evaluation Model.

CIPP merupakan singkatan dari Context, Input, Process, and Product. masing-masing dimensi tersebut dengan makna sebagai berikut: 1) Context, yaitu situasi atau latar belakang yang mempengaruhi perencanaan program pembinaan, 2) Input, kualitas masukan yang dapat menunjang ketercapaian program pembinaan, 3) Process, yaitu pelaksanaan program dan penggunaan fasilitas sesuai dengan apa yang telah direncanakan, 4) Product, yaitu hasil yang dapat dicapai dalam penyelenggaraan program tersebut

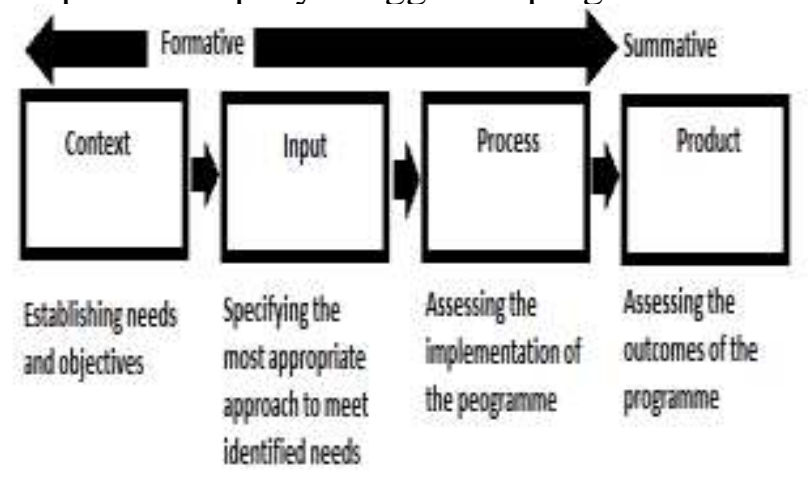

Bagan 1. Model Evaluasi CIPP (Muhaimin, 2015)

Context atau konteks merupakan upaya untuk menggambarkan dan merinci kebutuhan lingkungan. Secara spesifik Daniel L. Stufflebeam (2003) memberikan penjelasan bahwa context evaluation asess needs, problems, assets, and opportunities to help decision makers define goal and priorities and help the broader group of users judge goals, prioroties, and outcomes. Penjelasan tersebut berati bahwa evaluasi konteks menilai kebutuhan, masalah, aset, dan kesempatan untuk membantu pengambilan keputusan dalam mendefinisikan tujuan dan prioritas dan membantu kelompok lebih luas untuk tujuan prioritas dan hasil.

Input digunakan untuk mengidentifikasi kebutuhan dalam menjalanjan program atau kebijakan. Stuffelbeam (2003) menjelaskan bahwa input evaluation asses alternative appoaches, competing antion plans, staffing plans, and budgets for their feasibility and potential costeffectiveness to meet targeted needs and achieve goals. Pernyataan tersebut berarti bahwa evaluasi input menilai pendekatan alternatif, kegiatan rencana, rencana kepegawaian, dan anggaran untuk kelayakan dan potensi efektivitas biaya untuk memenuhi kebutuhan dan mencapai tujuan yang ditargetkan.

Evaluasi komponen proses digunakan untuk menyediakan umpan balik yang berkenaan dengan efisiensi pelaksanaan program atau kebijakan, termasuk di dalamnya pengaruh sistem dan pelaksanaannya. Stufflebeam (2003) menjelaskan bahwa process evaluation assess the implementation of the plans to help staff carry out activities and later help the broad group of users judge program performance and interpret outcomes. Pernyataan tersebut berati bahwa evaluasi proses menilai pelaksanaan rencana untuk membantu dalam melakukan kegiatan dan kemudian membantu menginterpretasikan hasil.

Evaluasi produk merupakan tahap akhir dari serangkaian evaluasi CIPP. Secara detail Stufflbeam (2003) menjelaskan bahwa product evaluation identify and asess outcomes intended, short term and long term both the help a staff keep an enterprise focused on achieving importans outcomes and ultimately to help the broader group of user gauge the effort's success in meeting targeted needs. Hal ini berarti upaya untuk mengidentifikasi dan menilai hasil yang 
diharapkan dan tidak diinginkan baik dalam jangka pendek maupun panjang.

CIPP merupakan model evaluasi yang tepat untuk melakukan penelitian terhadap masalah program pembinaan PELTI kota Palembang, sebab melakukan penelitian kualitatif dengan evaluasi program CIPP memiliki komponen-komponen yang di teliti lebih lengkap seperti Context, Input, Process dan Product dari keempat komponen tersebut dapat menjadi acuan untuk program pembinaan tenis lapangan PELTI kota Palembang untuk menjadi lebih baik lagi. Atas dasar model CIPP ini sehingga peneliti menggunakan model ini untuk dijadikan patokan untuk mengevaluasi program pembinaan tenis lapangan PELTI kota Palembang.

\section{Metode Penelitian}

Pendekatan yang digunakan dalam penelitian evaluasi program ini adalah CIPP Model. Stufflebeam (dalam Aip Badrujaman, 2011:54) berpendapat bahwa evaluasi seharusnya memiliki tujuan untuk memperbaiki (to improve) bukan untuk membuktikan (to prove). Penelitian evaluasi mencoba mencari jawaban, sampai seberapa jauh tujuan yang digariskan pada awal program tercapai atau mempunyai tanda-tanda akan tercapai. Secara umum terdapat dua jenis evaluasi, yaitu evaluasi formatif dan evaluasi sumatif. Evaluasi formatif biasa melihat dan meneliti pelaksanaan program tersebut. Evaluasi sumatif biasa dilaksanakan pada akhir program untuk mengukur apakah tujuan program tersebut tercapai.

Penelitian ini dilakukan di induk organisasi cabang olahraga tenis lapangan yaitu PELTI kota Palembang. Alasan peneliti mengambil kota Palembang sebagai daerah penelitian adalah: 1) Atlet tenis kota Palembang belum bisa bersaing ditingkat Nasional. 2) Belum sanggupnya PELTI kota Palembang menghasilkan atlet yang berkualitas untuk bersaing di tingkat nasional. Berkaitan dengan kualitas suatu peneliti, subyek penelitian yang sudah ditentukan seperti pengurus, pelatih, atlet dan masyarakat di sekitar pelatihan harus dapat menghasilkan gambaran yang reliabel atau dapat dipercaya. Dalam hal ini subyek yang dipilih haruslah betul-betul merepresentasikan keadaan yang sesungguhnya.
Selain itu penentuan subyek yang ideal dapat menentukan ketepatan hasil penelitian dengan menentukan penyimpangan standar dari perkiraan yang diperoleh.

Pengumpulan data adalah pencacatan peristiwa, hal-hal, keterangan- keterangan dan karakteristik atau seluruh elemen yang akan menunjang dan mendukung peneliti. Pengumpulan data dilakukan dengan menggunakan teknik-teknik tertentu, berdasarkan caranya di kenal beberapa pengumpulan data yaitu: angket wawancara, observasi, dokumentasi, dan analisis isi Dokumentasi untuk memperkuat data yang diperoleh dengan wawancara dan pengamatan langsung (observasi), peneliti juga menggunakan teknik dokumentasi di dalam pengumpulan data.Penelitian kualitatif data diperoleh dari berbagai sumber dengan menggunakan teknik pengumpulan data yang bermacam-macam (triangulasi) dan dilakukan secara terus menerus sampai datanya jenuh. (Sugiyono, 2010:333). Analisis data dapat dilakukan melalui kegiatan penyusunan dan penafsiran untuk menyusun kesimpulan. Karena keterkaitan dengan fenomena untuk dimaknai sesuai dengan latar alamiah, maka harus dipenuhi analisis data kualitatif, yaitu: naturalistik, analisis induksi dan holistik. Naturalistik, yakni analisisi data harus berdasarkan situasi nyata yang berubah secara alamiah, terbuka dan tidak ada rekayasa pengontrolan variabel. Analisis Induksi, yakni dengan mendasar prosedur berfikir induksi, mengungkapkan data khusus, detil, untuk menemukan kategori, dimensi, hubungan penting dan asli, yang diungkapkan dalam pertanyaan terbuka. Holistik, artinya totalitas fenomena harus dipahami oleh peneliti sebagai suatu sistem yang kompleks, keterkaitan menyeluru dan tidak dilihat secara parsipal.

\section{Hasil}

\section{Evaluasi Context}

Penelitian ini, evaluasi context meliputi aspek program pembinaan. Ketersediaan sarana dan prasarana, dukungan pemerintah terhadap program pembinaan yang dilakukan PELTI kota Palembang.

Program Pembinaan. Evaluasi context mengenai apakah PELTI kota Palembang memiliki program pembinaan jangka panjang untuk meningkatkan prestasi atlet tenis kota Palembang baik untuk di tingkat daerah maupun untuk tingkat nasional. Hasil dari wawancara di 
atas bahwa masih banyak kekurangan yang dilakukan pengcab PELTI kota Palembang, belum bisa menyelenggarakan program pembinaan jangka panjang. Untuk meningkatkan prestasi atlet baik di tingkat daerah maupun di tingkat nasional perlu sekali program pembinaan jangka panjang. Program yang dilaksanakan pengcab PELTI sekarang ini hanya program pembinaan yang sangat singkat, mengumpulkan atlet-atlet terbaik dikota Palembang menjelang pertandingan saja seperti pertandingan menjelang PORPROV atau POPDA, bahkan waktu yang dilaksanakan masih sangat singkat hanya berkisar satu sampai dua bulan. Program pembinaan jangka panjang yang dilasanakan secara sistematis dan terprogram mungkin prestasi atlet-atlet kota Palembang bukan ditingkat daerah saja tetapi bisa berprestasi ditingkat nasional juga walaupun memerlukan waktu yang lama.

Sarana dan Prasarana. Evaluasi selanjutnya yaitu evaluasi terhadap sarana dan prasarana yang dipergunakan untuk latihan atlet. Hasil penelitian yang dihimpun peneliti berdasarkan wawancara, observasi dan dokumentasi mengenai sarana dan prasarana selama peneliti bergabung kedalam lingkungan PELTI. Hasil evaluasi melalui wawancara, observasi dan dokumentasi terhadap kelayakkan sarana dan prasarana yang berupa penginapan atlet, lapangan, peralatan latihan hingga alat transportasi pada saat menjelang pertandingan cukup baik.

Dukungan Pemerintahan. Evaluasi berikutnya tentang dukungan pemerintah terhadap kemajuan prestasi atlet di kota Palembang. Hasil penelitian yang dihimpun peneliti dari hasil wawancara dan observasi mengenai dukungan pemerintah terhadap kemajuan prestasi atlet tenis kota Palembang. Hasil wawancara tentang dukungan pemerintah terhadap kemajuan prestasi atlet di kota Palembang, bahwa pemerintah kota Palembang memberikan dukungan berupa dana tahunan yang merupakan dana dari APBD daerah kota Palembang, dana yang diberikan APBD keseluruh pengcab sebesar 1 milyar untuk 34 pengcab, bantuan lainnya yaitu berupa alat transportasi dan penginapan yang diberikan pemerintah kota Palembang pada saat kegitan berlangsung.
Tabel 2. Hasil Analisis Evaluasi Context Pada PELTI kota Palembang

\begin{tabular}{cllc}
\hline \multirow{3}{*}{ No } & Aspek & \multicolumn{3}{c}{ Pencapaian } \\
\cline { 3 - 4 } 1. & Program Pembinaan & B & K \\
\hline 2. & Sarana Prasarana & & \\
\hline 3. & Dukungan Pemerintah & $\sqrt{ }$ \\
\hline
\end{tabular}

(Sumber Data: Hasil Wawancara, Observasi dan Dokumentasi)

Keterangan:

$\mathrm{B}=$ Baik,

$\mathrm{C}=$ Cukup baik, dan

$\mathrm{K}=$ Kurang

Indikator Program Pembinaan:

B: Program pembinaan jangka panjang yang berjalan secara sistematis

C: Program pembinaan jangka panjang yang tidak berjalan dengan sistematis

$\mathrm{K}$ : Program pembinaan yang dilaksanakan secara singkat

Indikator Sarana dan Prasarana:

B: Kelengkapan dan kelayakan sarana dan prasarana.

C: Kurang lengkap dan layaknya sarana dan prasarana.

$\mathrm{K}$ : Tidak lengkap dan tidak layaknya sarana dan prasarana

Indikator Dukungan Pemerintah:

B: Dukungan pemerintah yang baik.

C: Minimnya dukungan pemerintah

$\mathrm{K}$ : Tidak ada dukungan dari pemerintah

\section{Evaluasi Input}

Penelitian ini, evaluasi input meliputi aspek atlet, pelatih, dan asisten tingkat daerah. Pelatih, Asisten pelatih dan Atlet. Evaluasi input mengenai pelatih, asisten pelatih dan atlet di saat kejuaraan daerah seperti POPDA, PORPROV yang dapat dihimpun peneliti melalui wawancara dan dokumentasi selama berada di Palembang didalam lingkungan PELTI kota. Hasil wawancara dan hasil dokumen terkait pelatih, asisten pelatih pada saat kejuaraan tidak ada proses seleksi Pelatih karena pelatih yang berlisensi level one pada saat ini di kota Palembang hanya 1, dari tahun 2002 sampai sekarang untuk pelatih tenis kota Palembang tidak pernah melakukan pergantian pelatih, untuk 
asisten pelatih juga tidak ada proses seleksi khusus untuk memilih asisten pelatih hanya rekomendasi dari pengcab.

Atlet. Evaluasi input mengenai atlet di saat kejuaraan daerah seperti POPDA, PORPROV yang dapat dihimpun peneliti melalui wawancara dan dokumentasi selama berada di Palembang didalam lingkungan PELTI kota Palembang. Hasil wawancara di atas dapat diambil kesimpulan bahwa penyeleksian atlet kota Palembang melalui kegiatan daerah seperti POPDA dan PORPROV kota Palembang, tidak ada kegiatan khusus seperti mengadakan kompetisi-kompetisi antar klub-klub tenis yang ada di kota Palembang yang dilaksanakan PELTI untuk menjaring atau untuk mencari atlet-atlet yang berprestasi.

Dana. Evaluasi input yang terakhir adalah evaluasi terhadap dana pengurus cabang PELTI kota Palembang. Hasil peneliti yang bisa dikumpulkan peneliti berdasarkan wawancara observasi dan dokumentasi mengenai dana pengcab PELTI kota Palembang. Hasil wawancara, observasi dan dokumentasi selama peneliti melakukan penelitian, dapat disimpulkan bahwa dana untuk pengurus cabang PELTI berasal dari APBD kota Palembang dan tidak ada lagi pemasukan dana selain dari dana APBD kota Palembang.

Tabel 4. Hasil Analisis Evaluasi Process Pada PELTI kota Palembang

\begin{tabular}{|c|c|c|c|c|}
\hline \multirow{2}{*}{ No } & \multirow{2}{*}{ Aspek } & \multicolumn{3}{|c|}{ Pencapaian } \\
\hline & & B & $\mathrm{C}$ & $\mathrm{K}$ \\
\hline 1. & $\begin{array}{l}\text { Program } \\
\text { Latihan }\end{array}$ & & & $\sqrt{ }$ \\
\hline 2. & $\begin{array}{l}\text { Kesejahteraan } \\
\text { pelatih, asisten } \\
\text { pelatih dan atlet }\end{array}$ & & & $\sqrt{ }$ \\
\hline 3. & Transportasi & & $\sqrt{ }$ & \\
\hline
\end{tabular}

(Sumber Data: Hasil Wawancara, Observasi dan Dokumentasi)

Keterangan:

$\mathrm{B}=$ Baik,

$\mathrm{C}=$ Cukup baik, dan

$\mathrm{K}=$ Kurang
Indikator Program Latihan:

B : Berjalan sesuai dengan program

C : Memiliki program latihan tetapi banyak program yang tidak dilaksanakan

K : Tidak memilik program latihan.

Indikator Kesehjateraan Pelatih, Asisten Pelatih dan Atlet:

B : Baik.

C : Cukup

$\mathrm{K}$ : Kurang.

Indikator Transportasi:

B :Menggunakan transportasi khusus atlet.

C :Tidak ada transportasi khusus buat atlet tetapi pemerintah menyediakan alat transportasi buat atlet selama keguatan.

$\mathrm{K} \quad$ :Pemerintah tidak menyediakan alat transportasi untuk atlet .

Evaluasi Product

Penelitian evalausi Product ini meliputi aspek bagaimana keberhasilan program yang dijalankan pengurus PELTI kota Palembang. Hasil yang dapat dihimpun dari hasil wawancara, observasi, dan dokumentasi selama bergabung kedalam lingkungan PELTI. Dari hasil wawancara dan observasi memang untuk sekarang ini, persaingan tenis di kota Sumatera Selatan di tiap kegiatan, atlet kota Palembang masih sulit disaingi dengan kabupaten dari daerah lain. Kota Palembang selalu menjadi juara umum untuk pertandingan tenis di Sumatera Selatan, akan tetapi untuk bersaing ditingkat nasional atlet kota Palembang masih sulit bersaing untuk berprestasi di tingkat nasional.

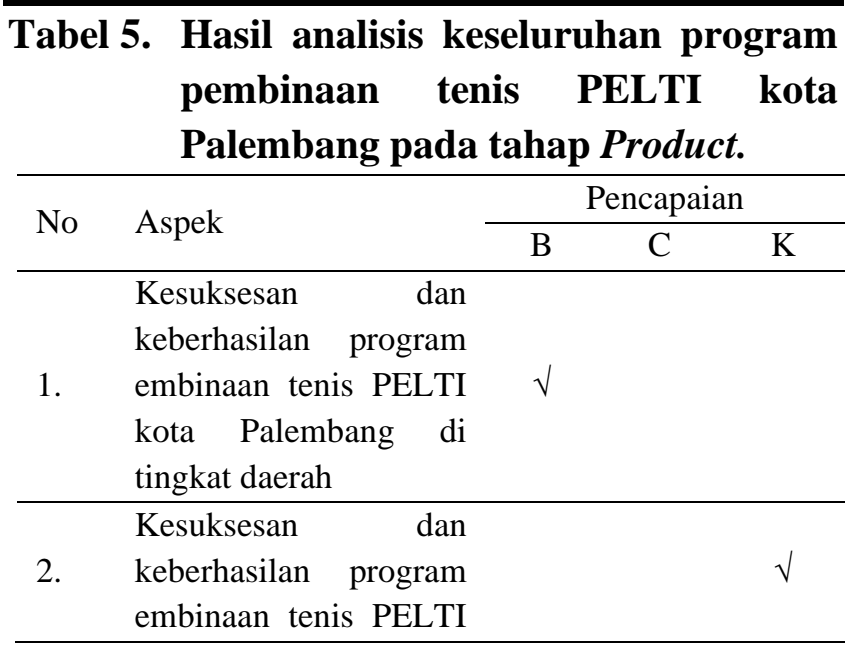


kota Palembang di

tingkat Nasional

(Sumber Data: Hasil Wawancara, Observasi dan Dokumentasi)

Keterangan:

B: Selalu berprestasi ditingkat daerah/nasional

C: Memiliki prestasi ditingkat daerah/nasional

$\mathrm{K}$ : Tidak pernah berprestasi daerah/nasional

\section{Simpulan dan Rekomendasi}

Pelaksanaan pembinaan tenis lapangan di kota Palembang yang dilakukan PELTI kota Palembang tidak berjalan dengan baik, dukungan pemerintah terhadap kemajuan prestasi tenis di kota Palembang masih sangat minim sekali. Input pembinaan atlet tenis lapangan kota Palembang masih banyak kekurangan untuk mencapai prestasi di tingkat nasional yaitu masih terjadinya program pembinaan yang instan. Proses pembinaan tenis lapangan di kota Palembang yang terdiri dari aspek pelaksanaan program latihan, kesejahteraan, serta transportasi yang terkait belum terlaksana dengan maksimal oleh pengurus berdasarkan data dan fakta secara nyata di lapangan. Product pembinan tenis lapangan kota Palembang belum mencapai prestasi ditingkat nasional, terbukti ditingkat POPWIL, Pra PON, dan PON atlet tenis lapangan kota Palembang belum bisa memperoleh hasil dan memberikan prestasi yang memuaskan untuk kota Palembang.

\section{DAFTAR PUSTAKA}

Aip, Badrujaman. 2011. Teori dan Aplikasi Evaluasi Program Bimbingan Konseling. Jakarta: Indeks.

Ariyanto, Muhammad Aziz. 2015. Evaluasi program Manajemen Pusat Pendidikan dan Latihan Olahraga Mahasiswa (PPLM) di Jawa Tengah. Disertasi. Jakarta: PPs. Universitas Negeri Jakarta.
Djaali dan Mujiono, Pudji. 2008. Pengukuran dalam Bidang Pendidikan. Jakarta: PT Gramedia.

Muhaimin, Mohammad. 2015. Model Evaluasi CIPP (Context, Input, Process, Product). http://www.kompasiana.com/muhaiminmo h/model-evaluasi-cipp-context-inputprocess-

product_552ab300f17e611530d62496.

Paton, Michael Quin. 2005. Utilization Facused Evaluation. California: Sage Publication, Inc.

Sugiyono. 2010. Metode penelitian Pendidikan Pendekatan Kualitatif, Kuantitatif, Dan R \& D. Bandung: ALFABETA

Stufflebeam, D.L. 2003. The CIPP Model Evaluation. Presented at the 2003 Annual Conference of the Oregon Program Evaluators Network (OPEN).

Undang-Undang Republik Indonesia Nomor 3 Tahun 2005 tentang Sistem Keolahragaan Nasional Pasal 20 ayat 3.

Wahjoedi. 2011. Bunga Rampai Hasil Penelitian Pembinaan Olahraga Tahun 2009. Jakarta: KEMENPORA. 